\title{
NATURAL HISTORY NOTE \\ Opportunistic predation of a silky short-tailed bat (Carollia brevicauda) by a tawny-bellied screech-owl (Megascops watsonii), with a compilation of predation events upon bats entangled in mist-nets
}

\author{
Catarina Serra-Gonçalves ${ }^{1,2,}{ }^{,}$, Adrià López-Baucells ${ }^{1,3,4}$, Ricardo Rocha ${ }^{1,4,5}$
}

\author{
${ }^{1}$ University of Lisbon, Centre \\ for Ecology, Evolution and \\ Environmental Changes (cE3c), \\ 1746-016 Lisbon, Portugal \\ Fragmentcal Dynamics of Forest \\ Institute for Amazonian \\ Research and Smithsonian \\ Tropical Research Institute, \\ Manaus, AM 69088-000, Brazil \\ ${ }^{5}$ University of Helsinki, \\ Metapopulation Research \\ Centre, FI-00014 Helsinki, Finland
}

Bat casualties caused by opportunistic predation of entangled animals during surveys employing mist-nets are scarcely reported in the scientific literature. Consequently, predator induced mortality associated with this sampling method is probably underestimated. Here, we report a predation attempt of a silky short-tailed bat (Carollia brevicauda) by a tawny-bellied screech-owl (Megascops watsonii) while the bat was entangled in the mistnet. The event took place in the Central Brazilian Amazon and represents the first report of bat predation attempt by this owl species. Additionally, we searched the literature for published records of bat predation during mist-net surveys since 1990. Twelve publications, covering at least 15 bat species and 11 predators, have reported opportunistic predation on entangled animals. We consider that predation of entangled animals is likely underreported and we recommend than in order to reduce opportunistic predation of entangled animals, researchers should: a) periodically visit the mist-nets every 15 to 20 minutes, and b) avoid that mist-nets reach ground-level once an animal becomes trapped.
\end{abstract}

*Corresponding author: catarinasg@gmail.com

DOI: https://doi.org/10.14709/BarbJ.10.1.2017.07

Keywords: mist-netting guidelines, Amazon, bat predation, diet, mist-nets, Strigidae, trophic interaction.

received: March, 28th 2017

accepted: November, 7th 2017

Compared to other small mammals (e.g. rodents or insectivores), bats do not tend to be impacted by high predation rates (Speakman et al. 1994, Kunz \& Fenton 2005). In fact, few species have specialized to prey upon bats (Macheiramphus alcinus and Falco rufigularis are two notable exceptions) and the majority of bat predatorinduced mortality relates to opportunistic captures by generalist predators such as owls (Carvalho et al. 2011, Vale-Gonçalves et al. 2015, Bergstrom \& Smith 2017), other birds (Lee \& Kuo 2001, Jung 2013), snakes (Rodríguez-Durán 1996), mammalian carnivores (Novaes et al. 2010, Mas et al. 2015, Rocha 2015), other bats (Oprea et al. 2006) and invertebrate such as spiders (Nyffeler \& Knornschild 2013) and centipedes (Molinari et al. 2005). Although Neotropical owls have been reported to capture and consume bats across several South and Central American localities (e.g. Ibañez et al. 1992, Motta \& Taddei 1992, Motta-Junior et al. 2004, Escarlate-Tavares \& Pessôa 2005, Motta-Junior 2006, Carvalho et al. 2011, Rocha \& López-Baucells 2014), bats appear to constitute only a minor component (0-5\%) of their diets (Escarlate-Tavares \& Pessôa 2005, Motta-Junior 2006).
Mist-netting is an effective survey method for many bat species (Meyer 2015). Yet, mist-nets need to be tended constantly since entangled animals can chew through the net and escape, and because entangled individuals are more vulnerable to predation (Breviglieri \& Pedro 2010, de Moraes Costa et al. 2016). Despite a wealth of studies employing mist-nets to study bats, predation of entangled individuals is rarely reported in the scientific literature. This lack of reports may suggest that predation upon entangled animals is rare, or that predation events are underreported. If the latter, this potentially leads to an underestimation of the consequences of scientific projects employing mist-nets upon local bat communities.

Here, we report the observation of a predation attempt of a silky short-tailed bat (Carollia brevicauda) by a tawnybellied screech-owl (Megascops watsonii) in the central Brazilian Amazon. In addition, we provide a compilation of opportunistic bat predation events published since 1990, and recommendations on how to reduce these instances. 

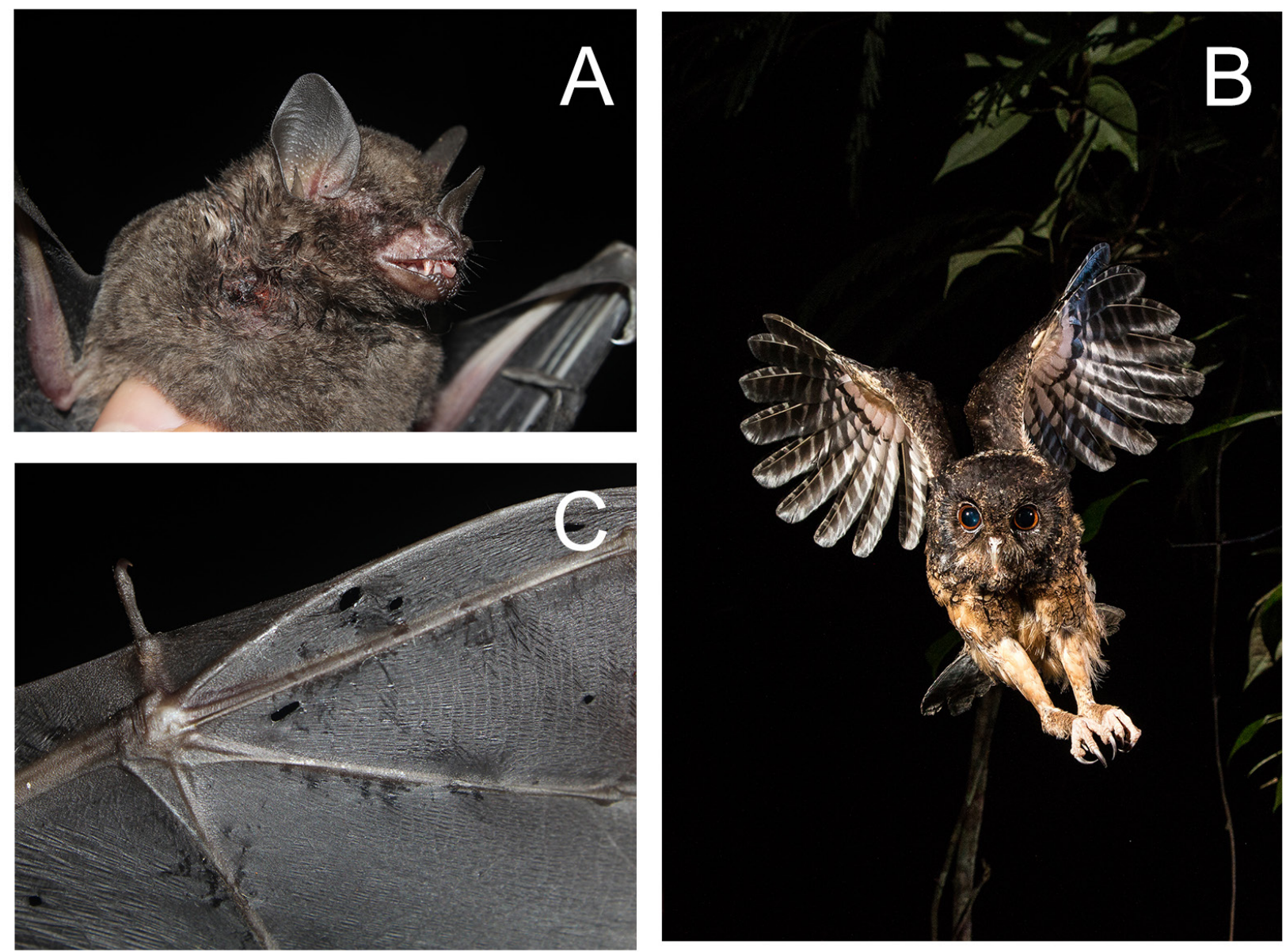

Fig. 1 - A) Carollia brevicauda with a neck injury caused by the Megascops watsonii. B) Megascops watsonii (@ Oriol Massana Valeriano \& Adrià López-Baucells) and C) details of claw perforations on the bat's wing membranes.

\section{Field observation}

The tawny-bellied screech-owl (Megascops watsonii) is a relatively small owl - 19 to $23 \mathrm{~cm}$ of length and mass between 114 and 155 g (Mikkola 2014) - with no sexual dimorphism. It has an extensive distribution in South American lowland rainforests, being chiefly associated with primary forest habitats. Its diet is poorly known but since the species forages in the lower levels of the canopy, it is thought to consist mainly of insects. Additionally, and similarly to other species in the genus Megascopus, it may occasionally prey upon small mammals and birds (König \& Weick 2010). One of the representatives of the genus Megascops ( $M$. asio) has been recorded to prey on bats (Wilson 1938, Barclay et al. 1982). However, to date, no bat species has been recorded as a prey of $M$. watsonii.

Carollia are understory frugivorous bats found throughout the tropical regions of Central and South America, from Panama to eastern Bolivia and southeastern Brazil (Gardner 2008). Although the Seba's short-tailed bat (Carollia perspicillata) has been reported as prey of several nocturnal raptors such as Tyto alba, Pulsatrix perspicillata and Strix virgata (Cloutier \& Thomas 1992, Motta \& Taddei 1992, Rocha \& López-Baucells 2014), its sister species, the silky short-tailed bat (Carollia brevicauda) has not yet been described as prey of any owl species. The species is generally uncommon in mature forests, whereas it is relatively abundant in second growth woodlands (Emmons \& Feer 1997, Reid 1997, dos Reis et al. 2007, Ferreira et al. 2017) where it acts as a major seed disperser of pioneering trees, with an emphasis on Piper spp. (Eisenberg 1989, Emmons \& Feer 1997, dos Reis et al. 2007). Although shorttailed fruit bats of the genus Carollia are among some of the most common vertebrates in Neotropical ecosystems, their predator-prey interactions are poorly known.

On 10 May 2014, during a bat survey at the Porto Alegre reserve, Biological Dynamics of Forest Fragments Project (BDFFP), Amazonas, Brazil (2²1'58.68's, 5958'6.71"W; for site description see Rocha et al. 2017), we observed a predation attempt of a bat in a mist-net by an owl. Bats were being sampled using 14 ground-level mist-nets (12 x $2.5 \mathrm{~m}, 16-\mathrm{mm}$ mesh, ECOTONE, Poland) open at dusk and remaining open for six hours. About one hour after the sampling session began (19:00 h), a M. watsonii was found entangled next to an inanimate bat. The dead bat presented multiple claw perforations and was identified was an adult male C. brevicauda (forearm $36.2 \mathrm{~mm}$; tibia $15.8 \mathrm{~mm}$; weight 12.75 g; Fig. 1) (López-Baucells et al. 2016).

The described event could be derived from the bat's increased susceptibility to predators as a consequence of being entangled in the mist-net (Fleming 1992). Although bats have been suggested to represent only a minor constituent of the diet of avian predators, the fear of bird 
Table 1 - Summary of opportunistic predation events on bats trapped during mist-net surveys (studies published between 1990 and 2016). Taxonomy follows Simmons (2005). "Represents the events where the predator identification is not confirmed (without direct observation).

\begin{tabular}{|c|c|c|c|}
\hline Predator order & Predator Species & Bat species & Publication \\
\hline Unknown & unknown & Carollia perspicillata & Nogueira et al. 2006 \\
\hline Anura & Leptodactylus vastus & $\begin{array}{l}\text { Glossophaga soricina } \\
\text { Tonatia bidens } \\
\text { Lonchophylla mordax } \\
\text { Myotis nigricans }\end{array}$ & Leite Filho et al. 2014 \\
\hline \multirow{3}{*}{ Carnivora } & Genetta genetta & Miniopterus schreibersii & Mas et al. 2015 \\
\hline & Cerdocyon thous & $\begin{array}{l}\text { Pygoderma bilabiatum* } \\
\text { Carollia perspicillata }\end{array}$ & Novaes et al. 2010 \\
\hline & Leopardus wiedii & $\begin{array}{l}\text { Artibeus fimbriatus } \\
\text { Artibeus jamaicensis } \\
\text { Artibeus lituratus } \\
\text { Sturnira lilium }\end{array}$ & Rocha-Mendes and Bianconi 2009 \\
\hline Chiroptera & Phyllostomus hastatus & $\begin{array}{l}\text { Glossophaga soricina } \\
\text { Carollia perspicillata } \\
\text { Myotis nigricans } \\
\text { Desmodus rotundus* } \\
\text { Anoura caudifera* }\end{array}$ & Oprea et al. 2006 \\
\hline \multirow{3}{*}{ Didelphimorphia } & Chironectes minimus & $\begin{array}{l}\text { Sturnira lilium } \\
\text { Carollia perspicillata }\end{array}$ & Breviglieri and Pedro 2010 \\
\hline & Didelphis albiventris & $\begin{array}{l}\text { Sturnira lilium } \\
\text { Artibeus lituratus }\end{array}$ & Gazarini et al. 2008 \\
\hline & Philander frenatus & $\begin{array}{l}\text { Anoura caudifera* } \\
\text { Desmodus rotundus } \\
\text { Myotis sp. } \\
\text { Desmodus rotundus* }\end{array}$ & Patricio-Costa et al. 2010 \\
\hline \multirow{3}{*}{ Strigiformes } & Pulsatrix perspicillata & Nyctinomops laticaudatus & Carvalho et al. 2011 \\
\hline & Bubo virginianus & Myotis lucifugus* & Jung et al. 2011 \\
\hline & Strix virgata & Carollia perspicillata & Rocha and López-Baucells 2014 \\
\hline
\end{tabular}

predation may still have a significant impact on bat behavior and eventually in their population dynamics (Speakman 1991, Lima \& O'Keefe 2013). The predation event here reported increases the scarce information about the opportunistic dietary behavior of $M$. watsonii. Predationprey relationships between bats and other vertebrates are poorly known and this is especially so for isolated areas such as Central Amazon. This constitutes the first record of Carollia brevicauda predation attempt by an owl species and represents the third case of owl predation upon netted bats during a 3 year-long study in the BDFFP (see: Rocha \& LópezBaucells 2014). Total capture effort of this 3 year-long study was 22070 mist-net hours (1 mist-net hour corresponds to one $12 \mathrm{~m}$ net open for 1 hour), during which 4244 bats of 48 species were captured (Rocha et al. 2017).

\section{Review of opportunistic predation of entangled bats}

To compile studies reporting predation of entangled bats during mist-net surveys, we have searched for publications with the words "predation" and "bat" in the title using the Harzing's Publish or Perish software version 4.26.1 (Tarma Software Research Ltd). The search was restricted to studies published between 1990 and 2017 and results were exported from Google Scholar. Additionally, the published events already published by Breviglieri \& Pedro (2010) were added to the list (personal communications were excluded).

A total of 156 publications met our search criteria. Of these, 12 publications reported a total of 30 opportunistic predation events of entangled bats (Table 1). Only three publications reported bat predation by owls, whereas nine reported predations by marsupials and seven by carnivores. One publication reported bats being captured by chiropteran species and one by an anuran.

The opportunistic predation attempt here reported and the additional 30 predation events identified during our literature review stress the need to consider field protocols that minimize the potential of predation on captured bats. This is especially true for the tropics, where most published casualties have been reported. Despite the apparent low number of casualties reported compared to the common high capture rates in the tropics, simple methodological modifications could be easily applied to minimize the number of accidents and improve animal safety without compromising research logistics and results. We therefore echo the recommendations suggested by Breviglieri \& Pedro 
(2010) and Carvalho et al. (2016) that, in order to reduce predation of captured animals, visits to the mist-nets should not be more than 15-20 min apart (most of the current guidelines suggest $30 \mathrm{~min}$ intervals between checks). Additionally, considering the high percentage of non-flying predators that have been reported to opportunistically prey on entangled animals, mist-nets should not reach groundlevel. As recommended by Carvalho et al. (2016), the proximity of the mist-net relatively to the ground once an animal is trapped can be checked by placing an object with a similar weight of the animals which are likely to be trapped in the lowest shelf of the mist-net. These suggestions must be tested in each region, and specifically adapted to local conditions, as risk of opportunistic predation is probably site- and time-specific. Depending on the purpose of the project and the target species these recommendations may have to be adapted (e.g. if researchers target Plecotus spp. - a passive 'whispering' gleaner bat species that captures prey from the ground and from low hanging vegetation - in a high montane habitat, they will probably need that the mist-nets reach the ground). Implementation of these recommendations could reduce instances of opportunistic predation of bats captured in mist-nets. Finally, field researchers should be encouraged to report casualties and injuries due to the capture or handling of animals, so that field methodologies can be improve and impacts on target and non-target species minimized.

\section{ACKNOWLEDGMENTS}

We would like to thank Christoph F.J. Meyer, Jorge Palmeirim and the BDFFP management team for assistance during all phases of the project and Rosely Hipólito, and Ary Jorge Ferreira for logistic support. We also would like to thank the financial support provided by the Portuguese Foundation for Science and Technology through the grants PTDC/BIABIC/111184/2009, SFRH/BD/80488/2011 and SFRH/BD/80488/2011. Additional funding was provided by a Bat Conservation International student research fellowship to R.R. This research was conducted under ICMBio permit (26877-2) and constitutes publication number 734 in the BDFFP technical series.

\section{REFERENCES}

BARCLAY, R., THOMSON, C. \& PHELAN, F. (1982). Screech owl, Otus asio, attempting to capture little brown bats, Myotis lucifugus, at a colony. Canadian Field-Naturalist, 96:205-206.

BERGSTROM, B. J. \& SMITH, M. T. (2017). Bats as predominant food items of nesting barred owls. Southeastern Naturalist, 16: N1-N4. http://dx.doi. org/10.1656/058.016.0110

BREVIGLIERI, C. P. B. \& PEDRO, W. A. (2010). Predação de morcegos (Phyllostomidae) pela cuíca d'água Chironectes minimus (Zimmermann, 1780) (Didelphimorphia, Didelphidae) e uma breve revisão de predação em Chiroptera. Chiroptera Neotropical, 16:732-739.
CARVALHO, L. F., CUNHA, N. L., FISCHER, E. \& SANTOS, C. F. (2011). Predation on Broad-eared bat Nyctinomops laticaudatus by the Spectacled Owl Pulsatrix perspicillata in southwestern Brazil. Revista Brasileira de Ornitologia, 19:417-418.

CARVALHO, W. D. D., NORRIS, D. \& MICHALSKI, F. (2016). Opportunistic predation of a Common Scale-backed Antbird (Willisornis poecilinotus) by a Goliath bird-eating spider (Theraphosa blondi) in the Eastern Brazilian Amazon. Studies on Neotropical Fauna and Environment, 51:239-241. https://doi.org/10.1080/01650521.2016.1 237802

CLOUTIER, D. \& THOMAS, D. W. (1992). Carollia perspicillata. Mammalian Species, 147: 1-9.

DE MORAES COSTA, L., DE OLIVEIRA TABOSA, L., LUZ, J.L. \& DE CARVALHO, W.D. (2016). Predadores naturais de morcegos no Brasil. Boletim da Sociedade Brasileira de Mastozoologia, 77: 131-142.

DOS REIS, N. R., PERACCHI, A. L., PEDRO, W. A. \& DE LIMA, I. P. (2007). Morcegos do Brasil. Universidade Estadual de Londrina. Londrina, Brasil, 256 pp.

EISENBERG, J. F. (1989). Mammals of the neotropics: the northern Neotropics. vol. 1. University of Chicago press. Chicago, USA, 550 pp.

EMMONS, L. H. \& FEER, F. (1997). Neotropical rainforest mammals: A field guide. University of Chicago Press. Chicago, USA, 396 pp.

ESCARLATE-TAVARES, F. \& PESSÔA, L. M. (2005). Bats (Chiroptera, Mammalia) in Barn Owl (Tyto alba) pellets in northern pantanal, Mato grosso, Brazil. Mastozoología Neotropical, 12:61-67.

FERREIRA, D. F., ROCHA, R., LÓPEZ-BAUCELLS, A., FARNEDA, F. Z., CARREIRAS, J. M., PALMEIRIM, J. M. \& MEYER, C. F. J. (2017). Season-modulated responses of Neotropical bats to forest fragmentation. Ecology and Evolution, 7: 4059-4071. https://doi.org/10.1002/ ece3.3005

FLEMING, T. H. (1992). Demography and natural history of the common fruit bat Artibeus jamaicensis, on Barro Colorado Island, Panama by CO Handley; DE Wilson; AL Gardner. The Oxford University Press. https://doi. org/10.2307/1382221

GARDNER, A. L. (2008). Mammals of South America, volume 1: marsupials, xenarthrans, shrews, and bats. University of Chicago Press. Chicago, USA, 696 pp.

GAZARINI, J., BRITO, J. E. C. \& BERNARDI, I. (2008). Predação oportunista de morcegos por Didelphis albiventris no sul do Brasil. Chiroptera Neotropical, 14:408-411.

IBAÑEZ, C., RAMO, C. \& BUSTO, B. (1992). Notes on food habits of the black and white owl. The Condor, 94:529531. https://doi.org/10.2307/1369226 
JUNG, T. S., LAUSEN, C. L., TALERICO, J. M. \& SLOUGH, B. G. (2011). Opportunistic predation of a Little Brown Bat (Myotis lucifugus) by a Great Horned Owl (Bubo virginianus) in southern Yukon. Northwestern Naturalist, 92: 69-72. http://dx.doi.org/10.1898/10-06.1

JUNG, T.S. (2013). Attempted predation of a diurnally active spotted bat (Euderma maculatum) by a belted kingfisher (Megaceryle alcyon). Canadian Field-Naturalist, 127: 346-347. http://dx.doi.org/10.22621/cfn.v127i4.1517

KÖNIG, C. \& WEICK, F. (2010). Owls of the World. 2nd Edition. Helm Identification Guides. London, United Kingdom, 528 pp.

KUNZ, T. H. \& FENTON, M. B. (2005). Bat ecology. University of Chicago Press. Chicago, USA, 798 pp.

LEE, Y. F. \& KUO, Y. M. (2001). Predation on Mexican freetailed bats by Peregrine Falcons and Red-tailed Hawks. Journal of Raptor Research, 35: 115.

LEITE FILHO, E., FEIJÓ, A. \& ROCHA, P.A. (2014). Opportunistic predation on bats trapped in mist nets by Leptodactylus vastus (Anura: Leptodactylidae). Revista Biotemas, 27: 205-208. http://dx.doi.org/10.5007/21757925.2014v27n3p205

LIMA, S. L. \& J. M. O'KEEFE. (2013). Do predators influence the behaviour of bats? Biological Reviews, 88: 626-644. http://dx.doi.org/ 10.1111/brv.12021

LOPEZ-BAUCELLS, A., ROCHA, R., BOBROWIEC, P., BERNARD, E., PALMEIRIM, J. \& MEYER, C. (2016). Field Guide to Amazonian Bats. INPA. Manaus, Brazil, 174 pp. https://doi.org/10.13140/RG.2.2.23475.84003

MAS, M., LÓPEZ-BAUCELLS, A. \& ARRIZABALAGA, A. (2015). Predation on bats by genets Genetta genetta (Linnaeus, 1758): a review. Journal of Bat Reserach \& Conservation, 8(1):5-11. http://dx.doi.org/10.14709/ BarbJ.8.1.2015.03

MIKKOLA, H. (2014). Owls of the World-A Photographic Guide. Firefly Books. Ontario, Canada, 528 pp.

MOLINARI, J. G., E. E., ASCENÇÃO, A. A., NASSAR, J. M., ARENDS, A., \& MÁRQUEZ, R.J. (2005). Predation by giant centipedes, Scolopendra gigantea, on three species of bats in a Venezuelan cave. Caribbean Journal of Science, 41: 340-346.

MOTTA, J. C., \& TADDEI, V. A. (1992). Bats as prey of Stygian Owls in southeastern Brazil. Journal of Raptor Research, 26: 259-260.

MOTTA-JUNIOR, J. C. (2006). Relações tróficas entre cinco Strigiformes simpátricas na região central do Estado de São Paulo, Brasil. Revista Brasileira de Ornitologia, 14: 359-377.
MOTTA-JUNIOR, J. C., ALHO, C. J. R., \& BELENTANI, S. C. S. (2004). Food habits of the striped owl Asio clamator in South-East Brazil. Raptors worldwide: proceedings of the VI world conference on birds of prey and owls ( $R$. Chancellor and B.-U. Meyburg, Eds.) World Working Group on Birds of Prey and Owls, MME BirdLife Hungary, Budapest. 777-784 pp.

MEYER, C.F. (2015). Methodological challenges in monitoring bat population-and assemblage-level changes for anthropogenic impact assessment. Mammalian Biology, 80: 159-169. https://doi.org/10.1016/j. mambio.2014.11.002

NOGUEIRA, M.R., MONTEIRO, L.R., \& PERACCHI, A. L. (2006). New evidence of bat predation by the woolly false vampire bat Chrotopterus auritus. Chiroptera Neotropical, 12: 286-288.

NOVAES, R. L. M., MENEZES JR., L. F., FAÇANHA, A.C.S., LOURO, M., CARDOSO, T.S., SANT'ANNA, C., FELIX, S., SILVARES, R., SIQUEIRA, A.C., SOUZA, R.F., DIASDE-OLIVEIRA, L. F. C., \& AGUIAR, M. V. P. (2010). Predação oportunista de morcegos por Cerdocyon thous (Carnivora, Canidae) no sudeste do Brasil. Chiroptera Neotropical, 16: 29-31.

NYFFELER, M., \& KNORNSCHILD, M. (2013). Bat predation by spiders. PLoS One, 8: e58120. http://dx.doi. org/10.1371/journal.pone.0058120

OPREA, M., VIEIRA, T. B., PIMENTA, V. T., MENDES, P., BRITO, D., DITCHFIELD, A. D., KNEGT, L. V., \& ESBÉRARD, C. E. L. (2006). Bat predation by Phyllostomus hastatus. Chiroptera Neotropical, 12: 255-258.

PATRICIO-COSTA, P., PIE, M. R., \& PASSOS, F. C. (2010). Ataques oportunísticos da cuíca Philander frenatus (Mammalia, Didelphidae) a morcegos em redes de neblina. Chiroptera Neotropical, 16: 40-41.

REID, F. (1997). A field guide to the mammals of Central America and Southeast Mexico. Oxford University Press. New York, USA, 334 pp.

ROCHA, R. (2015). Look what the cat dragged in: Felis silvestris catus as predators of insular bats and instance of predation on the endangered Pipistrellus maderensis. Journal of Bat Research \& Conservation, 8(1): 18-21. http://dx.doi.org/10.14709/BarbJ.8.1.2015.04

ROCHA, R., \& LÓPEZ-BAUCELLS, A. (2014). Opportunistic predation by Crested Owl Lophostrix cristata upon Seba's short-tailed bat Carollia perspicillata. Revista Brasileira de Ornitologia, 22: 35-37.

ROCHA, R., OVASKAINEN, O., LÓPEZ-BAUCELLS, A., FARNEDA, F.Z., FERREIRA, D.F., BOBROWIEC, P.E., CABEZA, M., PALMEIRIM, J.M., \& MEYER, C.F. (2017). Design matters: An evaluation of the impact of small man-made forest clearings on tropical bats using a before-after-control-impact design. Forest Ecology and Management, 401: 8-16. https://doi.org/10.1016/j. foreco.2017.06.053 
ROCHA-MENDES, F., \& BIANCONI, G. V. (2009). Opportunistic predatory behaviour of margay, Leopardus wiedii (Schinz, 1821), in Brazil. Mammalia, 73: 151-152. https://doi.org/10.1515/MAMM.2009.017

RODRÍGUEZ-DURÁN, A. (1996). Foraging ecology of the Puerto Rican boa (Epicrates inornatus): bat predation, carrion feeding, and piracy. Journal of Herpetology, 30: 533-536. https://doi.org/10.2307/1565698

SPEAKMAN, J. R. (1991). The impact of predation by birds on bat populations in the British Isles. Mammal Review, 21: 123-142. https://doi.org/10.1111/j.1365-2907.1991. tb00114.x
SPEAKMAN, J. R., LUMSDEN, L. F., \& HAYS, G. C. (1994). Predation rates on bats released to fly during daylight in south-eastern Australia. Journal of Zoology, 233: 318-321. https://doi.org/10.1111/j.1469-7998.1994. tb08593.x

VALE-GONÇALVES, H. M., BARROS, P., BRAZ, L., \& CABRAL, J. A. (2015). The contribution of the Barn Owl (Tyto alba) feeding ecology to confirm bat species occurrence in north Portugal. Journal of Bat Research \& Conservation, 8: 22-26. http://dx.doi.org/10.14709/BarbJ.8.1.2015.05

WILSON, K. A. (1938). Owl studies at Ann Arbor, Michigan. Auk, 55: 187-197. https://doi.org/10.2307/4078196 